leaving school, and the qualifications to which these lead. The manner in which the chart presents this information should foster a wider understanding of the ways in which the different 'stroams' of courses - university, sandwich and part-time-complement on $\theta$ another, and in particular the fact that the educational system makes provision for late developers to reach qualifications comparable with those accessible to people who are more fortunate at school. The chart is supplemented by lists of the universities and colleges at which the courses can bo taken, with brief notes on the content of metallurgical courses and the prospects for a career in metallurgy. The new pamphlet will be available during November at offices of the Youth Employment Sorvice, who are also circulating it to schools throughout the United Kingdom. Copins can also be obtained free of charge from the Institution of Metallurgists, 4 Grosvenor Gardens, London, S.W.1.

\section{Production of Clean Milk}

Atthough milk is one of the most valuable foods in our diet and cortainly the most important in the diet of children, it is a product the very nature of which allows it to be easily contaminated. There is, however, no need. for harmful contamination to occur, and it is vitally important that dairy farmers and all who deal with the dairy cow and hrr milk should be thoroughly acquainted with modern methods for the production of clean milk and for the prevention of any deterioration occurring in it, during what is often its long and tortuous journey from the cow to the consumer. Leaflet No. 82 , prepared by the Ministry of Agriculture of Northern Ireland, should do much to ensure the wholesomeness of the milk supplies in that part of the United Kingdom (The Production of Clean Milk. Pp. 18. Belfast: Ministry of Agriculture, 1963). In giving an excellent, though necessarily brief, summary of modern ideas and recommendations on the subject, it deals first with the cows thomselves, the buildings in which they are housed and their water supplies, and then procends to discuss the whole procedure of milking and the transfer of the milk to the dairy, and different methods of cooling and storing it. A short section on abnormal milk refers to the importance of not selling either to the creamery or to the consumer milk from a cow the udder of which has been treated by antibiotics until at least $72 \mathrm{~h}$ after the last treatment. There are valuable sections on detergents and sterilizing agents, and the pamphlet ends with sections on immersion cleaning and the care of equipment. The production of clean milk is, of courso, a subject on which volumes have been written, but in this short paper the points of greatest importance have been clearly and concisely dealt with in a way which everyone concerned should readily understand.

\section{Natural History at Oundle School}

ALTHобGH it contains little in the way of original work by boys, the annual report of the Oundle School Natural History Society for 1962 is valuable in showing what the interest of masters can do in fostering pursuit of natural history out of doors $\left(\mathrm{P}_{\mathrm{p}}\right.$ iii +23 . Oundle, Peterborough: Oundle School Natural History Society, 1963). One school visit to a reservoir enabled a group of boys to see a remarkable collection of wildfowl and other waders. Fifty-two different species of birds, including peregrine falcons, dippers, ring ouzels and redpolls, were recorded by another group of boys at a week-end camp. Expeditions were also made to study fungi, moths and molluses, the latter making the first record of Dreissina polymorphi in the Oundle district.

\section{Digital Vision}

DuRING the past year, reports of a remarkable case of 'digital vision' have percolated into Britain from the U.S.S.R. and have been the subject of articles in the lay Press. The subject, Rosa Kulesheva, a girl of twenty-two whose personality is admittedly abnormal, is said to have trained herself to distinguish colours and forms by means of her fingers and to be able to read books and newspapers by digital scanning alone. Her powers have been attested by at least two distinguished Soviet scientists, who have subjected her to a variety of tests. It has been shown, for example, that her reading is not impaired by interposing a plate of glass between the print and her fingers or by projecting the print on to a ground glass screen to exclude tactile sensation. It might, therefore, seem that the girl's fingers are genuinely sensitive to light. This dramatic and improbable claim has been critically examined by Dr. W. A. H. Rushton, reader in physiology in the University of Cambridge, in a letter to the Journal of the Society for Psychical Research (42, No. 717, 151; September 1963). As Dr. Rushton points out, the lack of any image-forming device and the relative poverty of the nerve supply to the fingers in comparison with that of the eye constitute seemingly fatal objections to the hypothesis of 'digital vision'. The available deseriptions, he adds, have left him unsatisfied that the precautions against deception were fully adequate. Although few will dissent from Dr. Rushton's conclusions it is perhaps only fair to withhold final opinion until the full report of the investigation, which is expected to appear in an English journal, becomes available.

\section{Spinoza in England 1665-1730}

A PAPER by Dr. Rosalie L. Colie in the June 19 issue of the Proceedings of the American Philosophical Society, entitled "Spinoza in England, 1665-1730", is a valuable account of a very complex phase in the philosophical outlook of the period. What she does is to attempt to play the part of an impartial observer-with considerable success - as British thinkers of several schools cross swords with the great Jewish scholar. In brief, his was a fierce attack on Christian orthodoxy, especially miracles. The English theologians stood at a marked disadvantage, in view of their weakness in Hebrew, compared with Spinoza's command of that language. On the whole, the Cambridge Platonists made little headway; their technique was frankly apologetic, though in the best tradition of contemporary style. As might be expected, the most rewarding duel was that between Robert Boyle and Spinoza (conducted, according to the fashion of the time, largely through an intermediary). The former, as an experimental chemist-and a loyal Anglican-was perfectly ready to admit miracles when such an extramundane phenomenon presented itself; and this without becoming involved in any extremes of dualism and the tenet of the 'absentee landlord'. Not the least important part of this contribution is a series of seven appendixes presenting the "Hitherto Unpublished Works of Robert Boyle relating to Spinoza and the Discussion of Miracles", in which the scientific aspect is closely examined in the light of the prevailing epistemology. We hear much of the "Catholic Rules of Motion", which reminds one of how essential it is to construe that adjective in its proper meaning of 'universal'.

It is of interest to note that the lecturers on the Robert Boyle Foundation were careful to speak to their brief as "A defence of natural and revealed religion". Richard Bentley, afterwards Master of Trinity, delivered the first set of sermons, and was careful to take Newton into his confidence during their preparation.

\section{The Late Stone Age in Eastern Africa}

MAgosI is an insignificant waterhole in N.E. Uganda; but the name has become attached to a late Stone Age prehistoric culture found at many sites in parts of eastern and southerm Africa. The site was first investigated and excavated as long ago as 1926 by E. J. Wayland, who was at the time the Government geologist in Uganda. The results were published in the Journal of the Royal 